\title{
Localization of Acetylcholine Receptors on Isolated CNS Neurons: Cellular and Subcellular Differentiation
}

\author{
William M. James' ${ }^{1}$ and William L. Klein ${ }^{2}$ \\ 'Department of Physiology, Yale University School of Medicine, New Haven, Connecticut 06510, and 'Department of \\ Neurobiology and Physiology, Northwestern University, Evanston, Illinois 60208
}

Significant progress has been made in determining regional expression of neurotransmitter receptors within the CNS, but little information is available at the neuronal level. In the current study, to begin characterizing cellular and subcellular aspects of receptor differentiation, we have localized ACh receptors on neurons isolated from the chicken CNS. Localization was determined autoradiographically using 2 cholinergic receptor probes: ${ }^{3} \mathrm{H}$-propylbenzilylcholine mustard (PrBCM) a muscarinic antagonist, and ${ }^{125} \mid-\alpha$-bungarotoxin (BTX), a putative nicotinic ligand in the avian CNS. To isolate neurons, we incubated embryonic chicken retinas (E13-E19) in $\mathrm{Ca}^{2+} / \mathrm{Mg}^{2+}$-free buffer containing 8 units/ml papain for $\mathbf{2 0} \mathrm{min}$ and then gently agitated the tissue by trituration. Large numbers of dendrite-rich neurons, belonging to recognizable morphological subpopulations (e.g., multipolar neurons of various sizes, small bipolar and unipolar neurons), were collected on slides for autoradiography. Cell isolation had no effect on ligand binding levels, and a high ratio of specific to nonspecific binding allowed us to associate silver grains with receptor position. Muscarinic-receptor-positive cells comprised a recognizable subpopulation that had small rounded cell bodies (6-7 $\mu \mathrm{m})$ and a single emergent arbor. The cells had an axial or elongated appearance. Muscarinic receptors were abundant over dendrites but absent from cell bodies. Segregation to dendrites was complete by $\mathrm{E} 13$, the age when synapses reportedly first begin to appear. Cells labeled with ${ }^{125} \mid-B T X$ were more heterogeneous in morphology. The most striking BTX-positive cells comprised neurons with large cell bodies ( $\sim 15$ $\mu \mathrm{m})$ and multiple processes. Dendrites were profusely labeled, but only sporadic labeling was seen on cell bodies, and often this was at sites crossed by labeled dendrites. Maximum labeling occurred in the distal, smallest-caliber ends of the dendritic arbors. All limbs of BTX-positive multipolar neurons expressed abundant receptors. Occasionally, a thin uniform-caliber process was seen branching from a primary dendrite, and such processes, which may have been axons, were never labeled. Very small neurons with bipolar morphology also showed minimal or no labeling on

\footnotetext{
Received Oct. 7, 1987; revised Mar. 30, 1988; accepted Apr. 1, 1988

Supported in part by NIH Grants NS21234 and DA03798 to W.L.K. The excellent typing of Madeline Kanner is gratefully appreciated. We thank Drs. Karen Lankford, James Sullivan, and Mary Lambert for their comments on the manuscript.

Correspondence should be addressed to William L. Klein, Interdepartmental Graduate Program in Neuroscience, Northwestern University, Hogan Hall, Evanston, IL 60208.

Copyright (C) 1988 Society for Neuroscience $0270-6474 / 88 / 114225-14 \$ 02.00 / 0$
}

one process, desplte dense labeling on the other. Photoreceptors and Mueller cells were never labeled with BTX or PrBCM. The data show that, within a discrete CNS region, specific subpopulations of neurons independently regulate expression of $\mathrm{ACh}$ receptors and that, even early in development, control mechanisms segregate receptors to physiologically appropriate regions of the cell surface.

One major approach to analyzing synaptic differentiation at the molecular level has involved localizing $\mathrm{ACh}$ receptors during embryonic development. Elegant cell biological studies of the neuromuscular junction have shown that early in development nicotinic ACh receptors (NAChRs) occur in microclusters over the entire muscle cell surface; as synaptic differentiation proceeds, signals from nerve cells cause receptors to accumulate almost exclusively within the synaptic region (reviewed in Schuetze and Role, 1987). It is not certain, however, that these important insights have direct applicability to receptor systems and cell surface differentiation within the CNS, as the skeletal muscle cell, with its single large synapse and nonbranching morphology, would appear to be a poor model for CNS neurons.

For the CNS, autoradiographic studies of ligand binding to tissue slices have provided considerable information about the occurrence of various neurotransmitter receptors in specific regions (Rotter ct al., 1979a, b; Morley and Kemp, 1981; Kuhar et al., 1986; Zarbin et al., 1986). However, it has been difficult to obtain information at the neuronal level because of the morphological complexity of CNS tissue and its considerable cellular heterogeneity (Kuhar, 1987). Two fundamental types of questions need to be answered: (1) For a given CNS region, which cells express the receptor? (2) Where on cell surfaces are the receptors placed?

One successful strategy for approaching the cellular complexities of CNS tissue has been pioneered by investigators studying the vertebrate retina. Functionally and developmentally, the retina is part of the brain (Dowling, 1975), and it is a useful model for developmental nerve cell biology (Adler and Farber, 1986). Using either microdissection or enzymatic dissociation, various investigators have been able to isolate single nerve cells as morphologically recognizable entities. These preparations have been used to characterize the neurochemical and electrophysiological properties of selected neurons (reviewed by Sarthy, 1986). We previously showed (James and Klein, 1982, 1984) that it was possible to autoradiograph the position of $\mathrm{ACh}$ receptors on identifiable neurons isolated from turtle retina. In the current work, we extend this approach to avian retina, a system more widely used for developmental and cell biological 


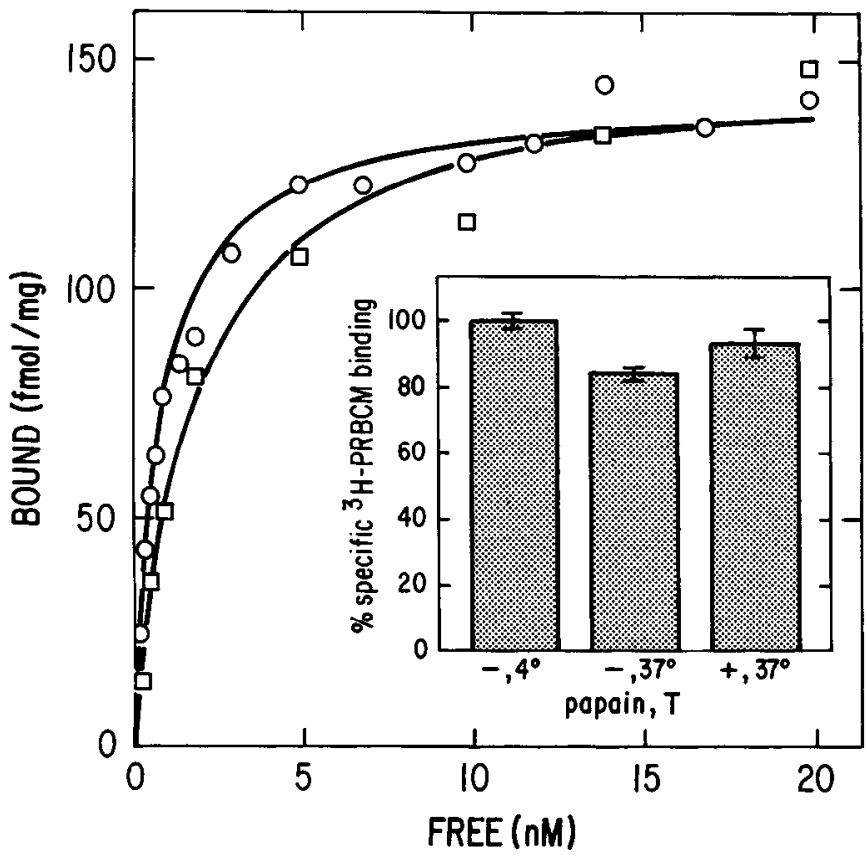

Figure 1. Equivalence of ligand binding site levels in dissociated and untreated E13 retina tissue. For nicotinic receptors, homogenates of retinas that were prepared as for cell dissociation (circles) or homogenates of control retinas (squares) were incubated with increasing concentrations of ${ }^{125}$ I-BTX. Specific binding was plotted after subtracting binding in the presence of $0.1 \mathrm{~mm} d$-tubocurarine. Both binding isotherms show saturable high-affinity binding. Analyses of Scatchard plots (not shown) gave dissociation constants of $1.9 \mathrm{~nm}$ with control and 0.86 nM with prepared tissue and maximum binding sites of $152 \mathrm{fmol} / \mathrm{mg}$ protein with control and $142 \mathrm{fmol} / \mathrm{mg}$ protein with prepared tissue. Inset, For muscarinic receptor determination, homogenates prepared as above were assayed both with $215 \mathrm{nM}{ }^{3} \mathrm{H}-\mathrm{PrBCM}$. The percentage bound was figured relative to the $4^{\circ} \mathrm{C}$ control condition. Binding levels normalized to protein were, respectively, 45,38 , and $42 \mathrm{fmol} / \mathrm{mg}$.

studies. AChRs, both nicotinic and muscarinic, of avian retina have been well characterized with respect to their biochemistry, development, and regulation (Vogel and Nirenberg, 1976; Sugiyama et al., 1977; Daniels and Vogel, 1980; Betz, 1983; Siman and Klein, 1983; Klein, 1984; Large et al., 1985a, b). The data reported here establish that cells of the avian retina are distinctly heterogeneous in expressing $\mathrm{AChR}$ phenotypes, that muscarinic receptors and nicotinic receptors occur on morphologically different nerve cell types, that the surface membranes of neurons are highly differentiated with respect to receptor placement, and that this subcellular differentiation occurs during the earliest periods of retinal synaptogenesis.

\section{Materials and Methods}

Media and conditions that were used to prepare chick retina cells with muscarinic- or nicotinic-labeled AChR were as follows. Retinas of 13-
$18 \mathrm{~d}$ (E13-E18) embryonic chickens were dissected into Hanks salts without $\mathrm{Ca}^{2+}$ or $\mathrm{Mg}^{2+}$ (Hanks-CMF in gm/liter: $\mathrm{KCl}, 0.4 ; \mathrm{KH}_{2} \mathrm{PO}_{4}$, $0.06 ; \mathrm{NaCl}, 8.0 ; \mathrm{Na}_{2} \mathrm{HPO}_{1}, 0.09 ;$ D-glucose, 1.0 ; phenol red, 0.01 ; Sigma) buffered with HEPES $\left(6.0 \mathrm{gm} / \mathrm{liter}\right.$; Sigma) at $\mathrm{pH} 7.4,37^{\circ} \mathrm{C}$, also containing EDTA $(0.38 \mathrm{gm} /$ liter; Sigma) and papain $(0.5 \mathrm{gm} /$ liter; Sigma P-3125). Retinas incubated for 20 min were next washed 6 times during $10 \mathrm{~min}$ in Hanks-CMF also containing BSA ( $2.0 \mathrm{gm} /$ liter; Sigma) at $37^{\circ} \mathrm{C}$. At this point, receptors were labeled by one of the following methods.

For nicotinic receptor labeling, retinas were minced and placed in $125 \mathrm{I}-\alpha$-bungarotoxin (BTX; specific activity $=120-60 \mathrm{Ci} / \mathrm{mmol} ;$ New England Nuclear) diluted to $5.0 \mathrm{~nm}$ in Hanks-CMF for $30 \mathrm{~min}$ at $37^{\circ} \mathrm{C}$ (Vogel and Nirenberg, 1976). Nonspecific labeling was determined in the presence of $0.1 \mathrm{~mm} d$-tubocurarine. Retina pieces were chilled to $4^{\circ} \mathrm{C}$ and were then washed 6 times during 10 min in Hanks-CMF containing BSA (2.0 gm/liter) and once more in complete Hanks (in gm/ liter: $\mathrm{CaCl}_{2}$ dihydrate, $0.185 ; \mathrm{MgCl}_{2}$ dihydrate, $0.1 ;$ Sigma) and DNAase I $(0.1 \mathrm{gm} / \mathrm{liter}$; Sigma). Cells were dissociated by gentle trituration through a Pasteur pipette at room temperature; then, all visible tissue was allowed to settle for $5 \mathrm{~min}$ before the cell suspension was withdrawn. The cells were then chilled over ice and were mixed with an equal volume of glutaraldehyde ( $2 \%$; Sigma).

For muscarinic receptor labcling, cells were dissociated in ${ }^{3} \mathrm{H}$-propylbenzilylcholine mustard (PrBCM; specific activity $=30.0 \mathrm{Ci} / \mathrm{mmol}$; New England Nuclear) diluted to $2.5 \mathrm{~nm}$ in Hanks-CMF. Prior to dilution, an aliquot of ligand was activated (ionized) as a $1.0 \mu \mathrm{M}$ stock

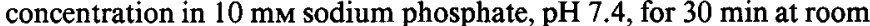
temperature (Burgen et al. 1974; Rotter et al., 1979a, b). Cells were incubated in ${ }^{3} \mathrm{H}$-PrBCM for $20 \mathrm{~min}$ at $30^{\circ} \mathrm{C}$; sodium thiosulfate stock was then added to $1.0 \mathrm{~mm}$ concentration, and unbound aziridinium ion was allowed to quench for $10 \mathrm{~min}$. Nonspecific labeling was determined in the presence of $0.4 \mu \mathrm{M}$ atropine sulfate. Cells were then chilled and fixed.

All cells in the suspensions were then harvested, washed, and plated on microscope slides as previously described (James and Klein, 1984). Drops of cell suspensions were applied to a floating filter (3; polycarbonate, $5 \mu \mathrm{m}$ pores; Nuclepore) on an iced solution of $1 \%$ glutaraldehyde in $100 \mathrm{~mm}$ sodium phosphate buffer, $\mathrm{pH}$ 7.4. Fixation was allowed for $30 \mathrm{~min}$ on ice, during which time preparations were drained and refilled with fixative several times so as to wash out unbound ligand. All preparations were then washed by draining the reservoir and refilling with phosphate buffer ( $20 \mathrm{~mm}$, pH 7.4) 6 times during $1 \mathrm{hr}$. Cells were transferred to chilled microscope slides that were pretreated with poly(Llysine) hydrobromide (0.1 gm/liter; 300,000 MW; Sigma). Filters were inverted and lowered gently to the surface of slides, and were drained by wicking until contact was made. Slides supporting cells were then inserted at an acute angle into iced distilled water, causing the filter to peel away on the water surface, and specimens were air-dried in a coldroom.

Slides were dipped in autoradiographic emulsion (Kodak NTB2 or Ilford L4) diluted 1:1 with distilled water and exposed 42-135 d over anhydrous $\mathrm{CaSO}_{4}$ (Drierite) desiccant. Emulsion was developed with Kodak D-19 (1:1) at $15^{\circ} \mathrm{C}$ for 4 min and fixed with $2.5 \%$ sodium thiosulfate $0.5 \%$ sodium bisulfite for $5 \mathrm{~min}$. Some slides were counterstained with toluidine blue (Baughman and Bader, 1977). Photomicrographs were obtained using double oil-immersion phase optics (Zeiss).

Receptor levels were estimated from grain counts in photomicrographs of randomly selected neurons in each preparation. Muscarinic calculations were based on the formula (Lane et al., 1977)

$$
N=(n d / t)\left(A / S_{0} C\right) \text {, }
$$

where $N$ is the number of receptors per cell, $n$ is the number of developed grains counted over a cell, $d$ is the number of ${ }^{3} \mathrm{H}$ decays associated with

Figure 2. Laminar organization of nicotinic and muscarinic receptor labeling in partly dissociated pieces of tissue. Thin pieces of retina were incidentally obtained during the cell-dissociation procedure and autoradiographed after BTX $(A-D)$ and $\operatorname{PrBCM}(E-J)$ labeling. Tissue structure demonstrated the typical 3 cell layers and 2 synaptic layers. For BTX, grains developed mostly within synaptic layers, shown here at age E16 $(A$ and $B$ ). Photos are given as vertical pairs; phase-contrast mode (above) shows laminar structure and bright-field mode (below) shows grains; open triangles in lower photos indicate the outer synaptic layer. Nonspecific binding in the presence of $d$-tubocurarine $(C$ and $D)$ was low relative to total BTX labeling. PrBCM bound to the inner synaptic layer, as shown at E18-19 ( $E$ and $F$, $G$ and $H$ ). Nonspecific labeling in the presence of atropine blocked was low $(I$ and $J)$. Scale bars $(A$ and $B), 30 \mu \mathrm{m}$. 

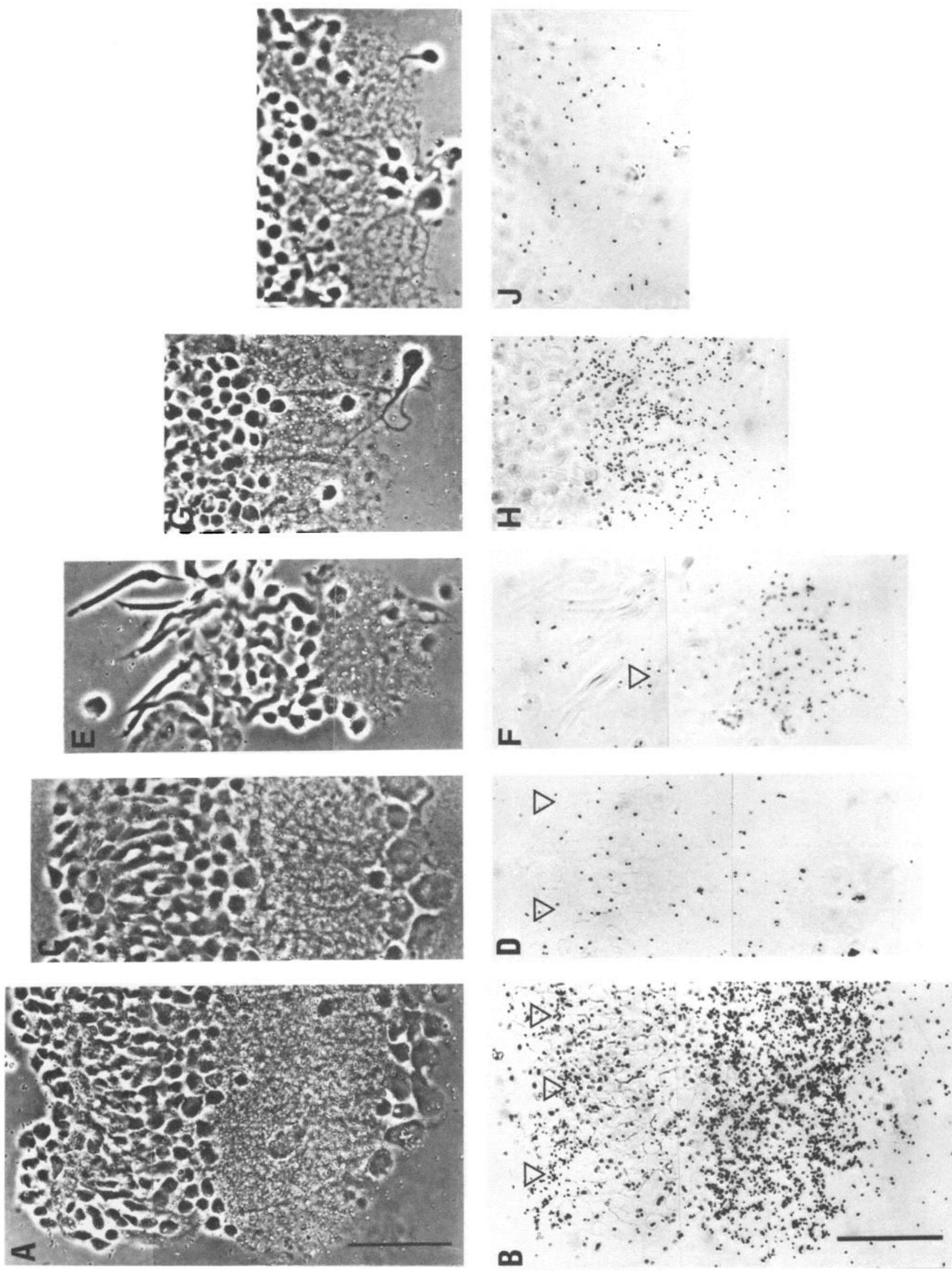

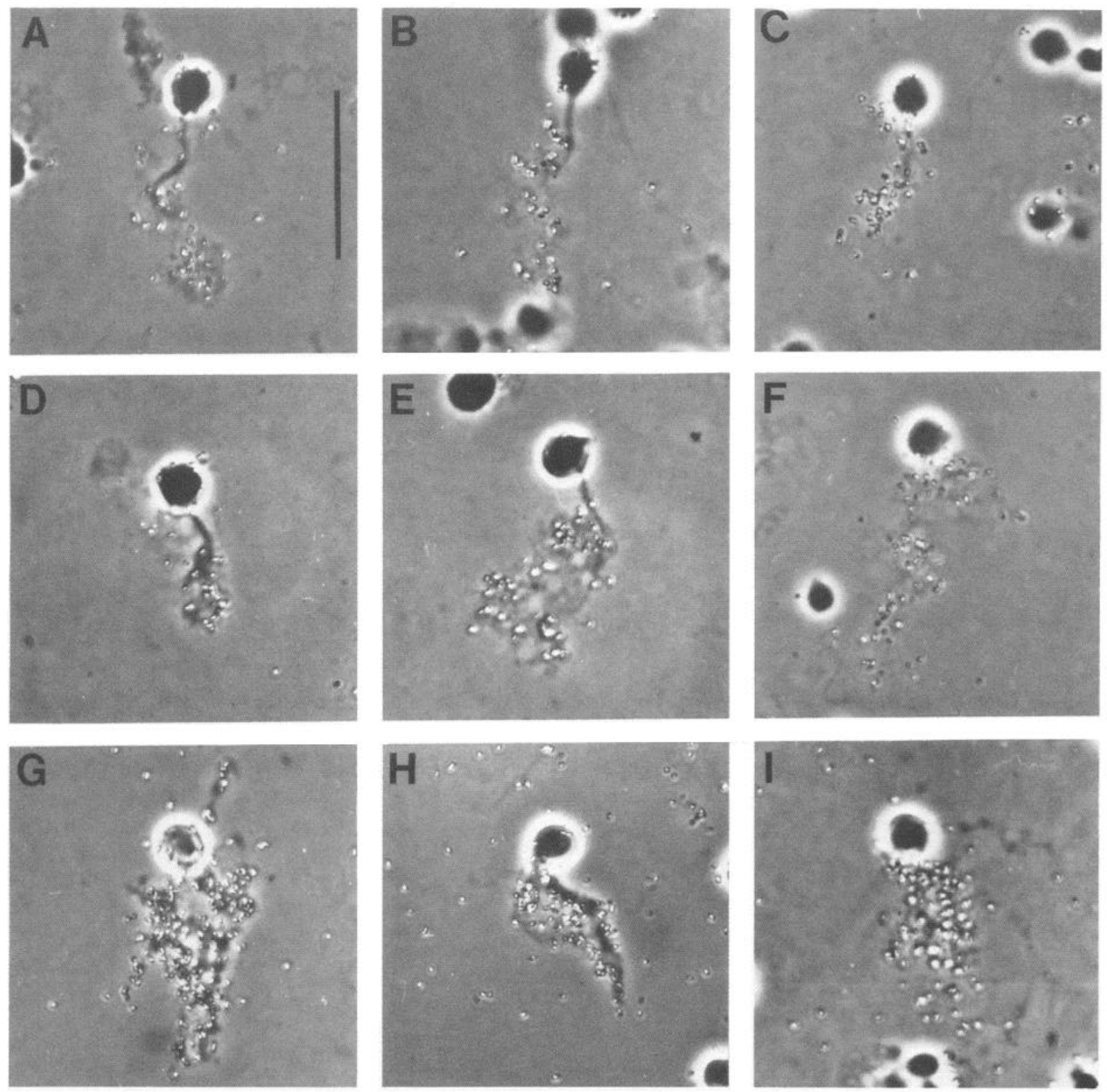

Figure 3. Characteristic appearance of neurons labeled with ${ }^{3} \mathrm{H}-\mathrm{PrBCM}$. Silver grains associated with specific ${ }^{3} \mathrm{H}-\mathrm{PrBCM}$ labeling identified a set of neurons that had the consistent morphology shown here. Muscarinic neurons had apparent dendrites that were decorated with multiple grains. The dendritic arbor emerged only from one side of the cell body, giving an elongated asymmetric appearance to the receptor-positive cell population. The extent of the dendritic arbor was typically $<30 \mu \mathrm{m}$, and the cell bodies had a diameter of $6-7 \mu \mathrm{m}$. Few grains occurred on the cell body, but the dendrites were profusely labeled. When a single proximal shaft was present, almost all of the receptors appeared to be localized to the periphery rather than the proximal segment $(A, B, D, E$, and $H)$. Scale bar $(A), 20 \mu \mathrm{m}$.

one developed grain (the reciprocal of emulsion efficiency), $t$ is the exposure time (d), $A$ is Avogadro's number $\left(6 \times 10^{20} \mathrm{molecules} / \mathrm{mmol}\right)$, $S_{0}$ is the specific activity of PrBCM, and $C$ is the number of decays per Curie $\left(3.25 \times 10^{15}\right.$ decays/d). We assumed an emulsion efficiency for ${ }^{3} \mathrm{H}$ of approximately 0.25 (Lane et al., 1977; Hartzell, 1980; Siegel and Fischbach, 1984). Nicotinic sites per cell were estimated using the formula (modified from Fertuck and Salpeter, 1976)

$$
N=\frac{n d}{(1440 \mathrm{~min} / \mathrm{d} \times T / \ln 2)\left(1-e^{-\ln 2 \times(/ / T)}\right)} \times \frac{A}{S_{0} C},
$$

where $N, n, d$, and $t$ are the identical or analogous terms and $T$ is the half-life of ${ }^{125} \mathrm{I}(60 \mathrm{~d})$. Two ${ }^{125} \mathrm{I}$ decays were assumed to be associated with development of one silver grain. Receptor binding levels in each preparation was routinely measured as described previously (Siman and Klein, 1983; James and Klein, 1984) using a standard filtration assay and liquid scintillation counting.

\section{Results}

Assessment of ligand binding

To verify that the cell isolation protocol did not alter receptor levels, we first compared the specific binding of radioligands to homogenates of dissociated and undissociated retina tissue (Fig. 1). Control and papain-treated retinas showed essentially the same level of displaceable, high-affinity binding sites for the reversible nicotinic ligand ${ }^{125} \mathrm{I}$-BTX. Maximum binding and $K_{d}$ values were $142 \mathrm{fmol} / \mathrm{mg}$ protein and $1.9 \mathrm{~nm}$ for control tissue versus $152 \mathrm{fmol} / \mathrm{mg}$ protein and $0.9 \mathrm{nM}$ for treated tissues. Binding of the covalent muscarinic ligand ${ }^{3} \mathrm{H}-\mathrm{PrBCM}$, measured under optimum standard reaction conditions, also gave identical levels of specific binding for control and dissociated tissue (Fig. 

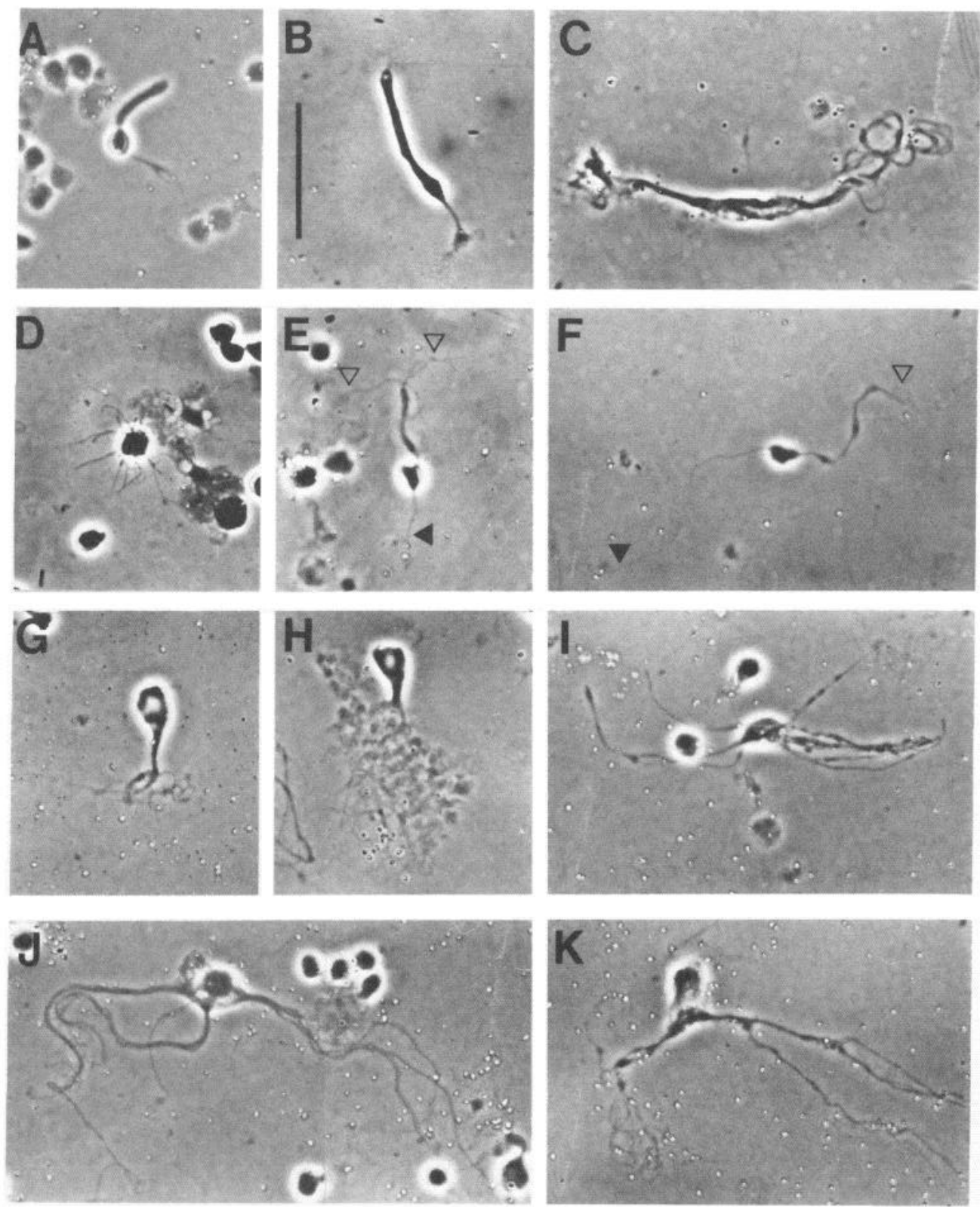

Figure 4. Cell not labeled with ${ }^{3} \mathrm{H}-$ PrBCM. Dissociation protocol provided a wide variety of consistently recognizable morphological cell types. Cells not resembling those in Figure 3 were never labeled by ${ }^{3} \mathrm{H}-\mathrm{PrBCM}$, as illustrated in the autoradiographs shown here. Consistently recognizable cell nonmuscarinic cells included $(A$ and $B)$ photoreceptors; $(C)$ Mueller cells (neuroglia); $(D)$ small multipolar cells; $(E$ and $F$ ) presumed bipolar cells (branched possible dendrites marked with open triangles, possible axon marked with black triangle); $(G$ and $H$ ) apparent unipolar cells; and $(I-K)$ various multipolar cells. Scale bar $(B), 30 \mu \mathrm{m}$.
1 , inset). The procedures used to dissociate retina tissue into individual cells therefore did not decrease the number of binding sites for either ligand used for autoradiography.

\section{Specific binding in autoradiographs of partially dissociated retina}

Mechanical dissociation following papain treatment was deliberately gentle so as to minimize cell breakage. Besides single cells, this treatment frequently gave multicellular pieces that resembled cross sections of undissociated tissue. Such fragments had the 5 layers characteristic of retina (Fig. 2). Autoradiographs showed abundant binding in the plexiform (synaptic) layers but much less in the nuclear (cell-body) layers. The inner plexiform layer bound both $\operatorname{PrBCM}$ and BTX, but the outer plexiform bound only BTX.

Background levels of silver grains were low for both ligands (Fig. 2, $C, D, I, J)$. Nonspecific grain distributions were deter- mined in the presence of $100 \mu \mathrm{M} d$-tubocurarine for ${ }^{125} \mathrm{I}-\mathrm{BTX}$ and $10 \mu \mathrm{M}$ atropine for ${ }^{3} \mathrm{H}-\mathrm{PrBCM}$. The great difference between total and nonspecific labeling in the retina pieces assured us that the position of silver grains largely reflected the position of ligand binding sites. Labeling of individual cells similarly was eliminated by incubation with nonradioactive ligands (not shown). However, since most cells were unlabeled by either ${ }^{3} \mathrm{H}-$ PrBCM or ${ }^{125}$ I-BTX, the effects of unlabeled antagonists were best seen in the tissue pieces.

\section{Cellular localization of muscarinic receptors}

The pattern of ligand binding in the retinal pieces of Figure 2 resembles the laminar placement reported for sectioned retina (Sugiyama et al., 1977). In such undissociated tissue, here as well as in slices, it is impossible to describe particular cells associated with specific ligand binding or to determine the positioning of receptors on a given cell. Therefore, to find which 

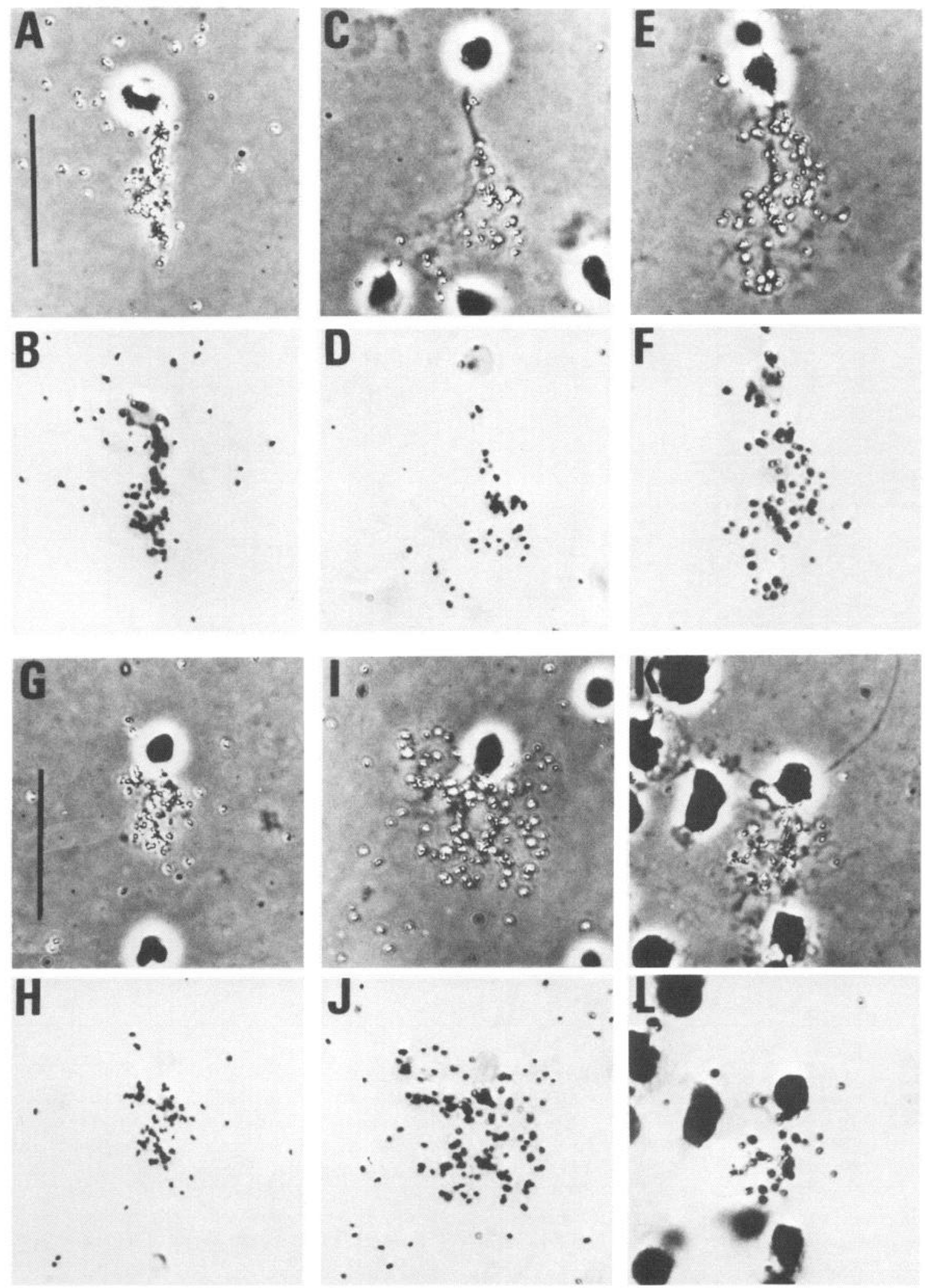

Figure 5. Early embryonic development of muscarinic localization. Cells were isolated from E13 (left column), E17 (middle column), and E19 (right column) retinas. During this period, there were no obvious changes in the morphology of muscarinic receptor-positive cells, although the dendritic arbors had a tendency to appear more elongated and elaborate. At all ages, dendrites were decorated with grains, but cell bodies were not. Photos pair phase-contrast (upper rows) and bright-field (lower rows) images. Pair $K-L$ was counterstained with toluidine blue. The numbers of receptors expressed per cell as calculated (equation 1) from the grain counts demonstrated here were typically near $4 \times 10^{4}$. Scale bars $(A$ and $G), 30 \mu \mathrm{m}$. 

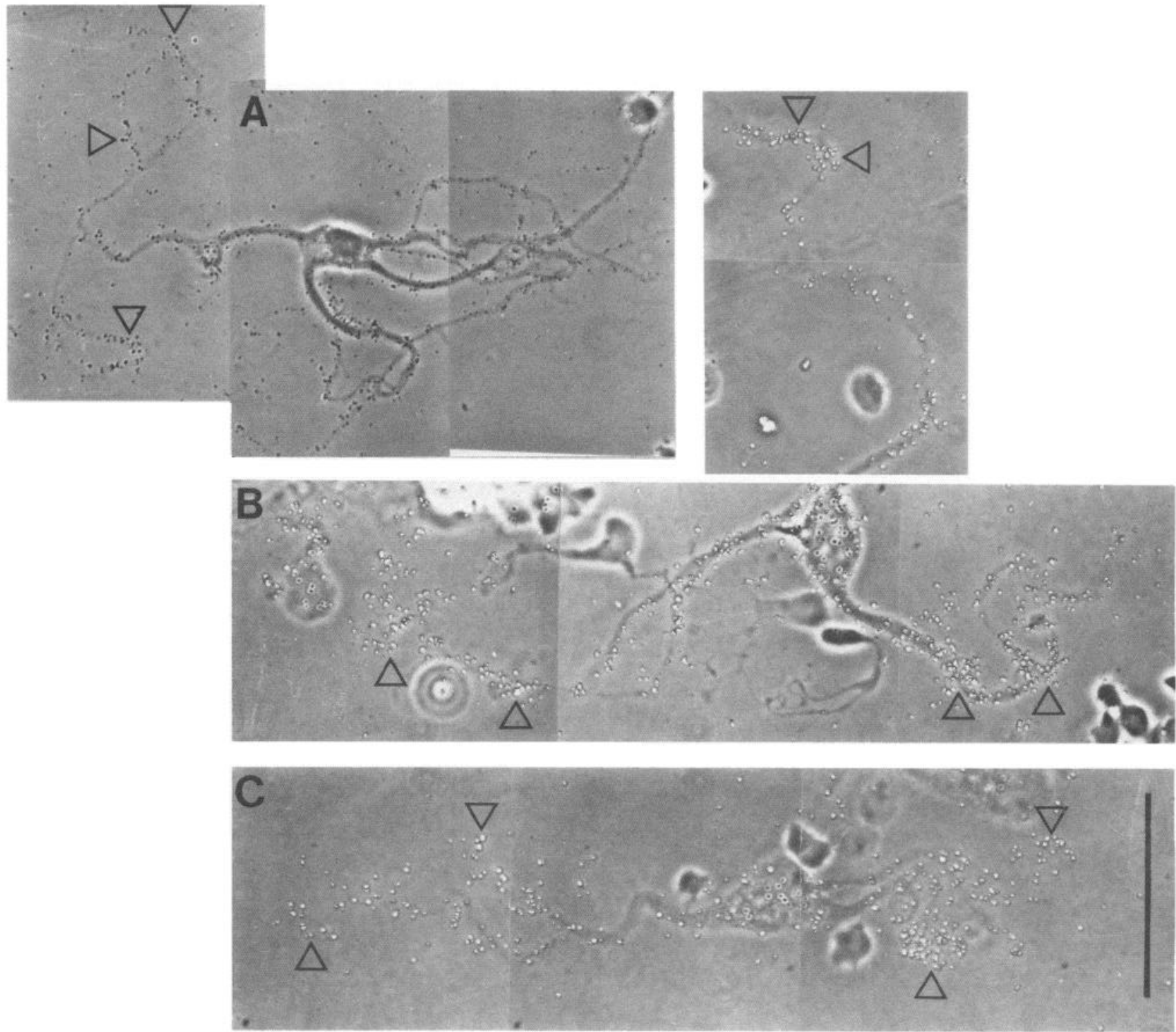

Figure 6. Dendritic localization of BTX receptors in large multipolar neurons. Dissociated cells that had BTX receptors generally were varied both in size and shape; the largest of these neurons, shown here, were multipolar cells with an extent exceeding $100 \mu \mathrm{m}$. Receptors were sparse on the cell body and proximal segments of the dendritic arbor, but narrower peripheral branches were densely decorated. These peripheral branches sometimes were folded back upon the cell body. Receptor clusters at the periphery of most processes are indicated by open triangles. Numbers of binding site per cell from E16 retina were typically very near $5 \times 10^{4}$ (calculated using equation 2 ). Scale bar $(C), 30 \mu \mathrm{m}$.

morphological classes of cells bound ${ }^{3} \mathrm{H}-\mathrm{PrBCM}$ and ${ }^{125} \mathrm{I}-\mathrm{BTX}$ and to establish the subcellular disposition of the binding sites, we next prepared and analyzed autoradiographs of isolated cells. The total number of cells examined, obtained from multiple preparations, was estimated to be in excess of 1000 .

An easily recognized subpopulation of retinal cells was consistently labeled with ${ }^{3} \mathrm{H}-\mathrm{PrBCM}$ (Fig. 3). Muscarinic receptorpositive cells had small rounded cell bodies $(6-7 \mu \mathrm{m})$ and a single emergent arbor that gave the cells an axial or elongated appearance. This subpopulation showed subtle morphological differences that suggested the presence of either more elongated or more bushy appearances (cf. Fig. 3, $A$ and $I$ ), but all examples of muscarinic receptor-positive cells appeared to be of the same basic morphological family.

Although the receptor-positive cells greatly resembled one another, not all cells of this morphological class expressed re- ceptors, and the number of cells that were muscarinic-receptorpositive was relatively small. Cell culture studies previously indicated that only about $2 \%$ of the entire retina cell population is receptor positive (Large et al., 1985a). In the present work, which has focused on the qualitative nature of cellular and subcellular localization, no attempt was made to establish the percentage of cells within the retina that was receptor positive, as the presence of random clumps of nondissociated cells would make such calculations imprecise. There was, however, no indication of preferential dissociation of certain cell types, and wide varieties of cell morphologies were seen. Muscarinic receptor-positive cells, with their nearly homogeneous morphology, stood apart from the highly varied kinds of cells that were never labeled by ${ }^{3} \mathrm{H}-\mathrm{PrBCM}$ (Fig. 4; see below). Unlabeled cells included photoreceptor and Mueller cells, as well as a gamut of others with different sizes and branching patterns. 

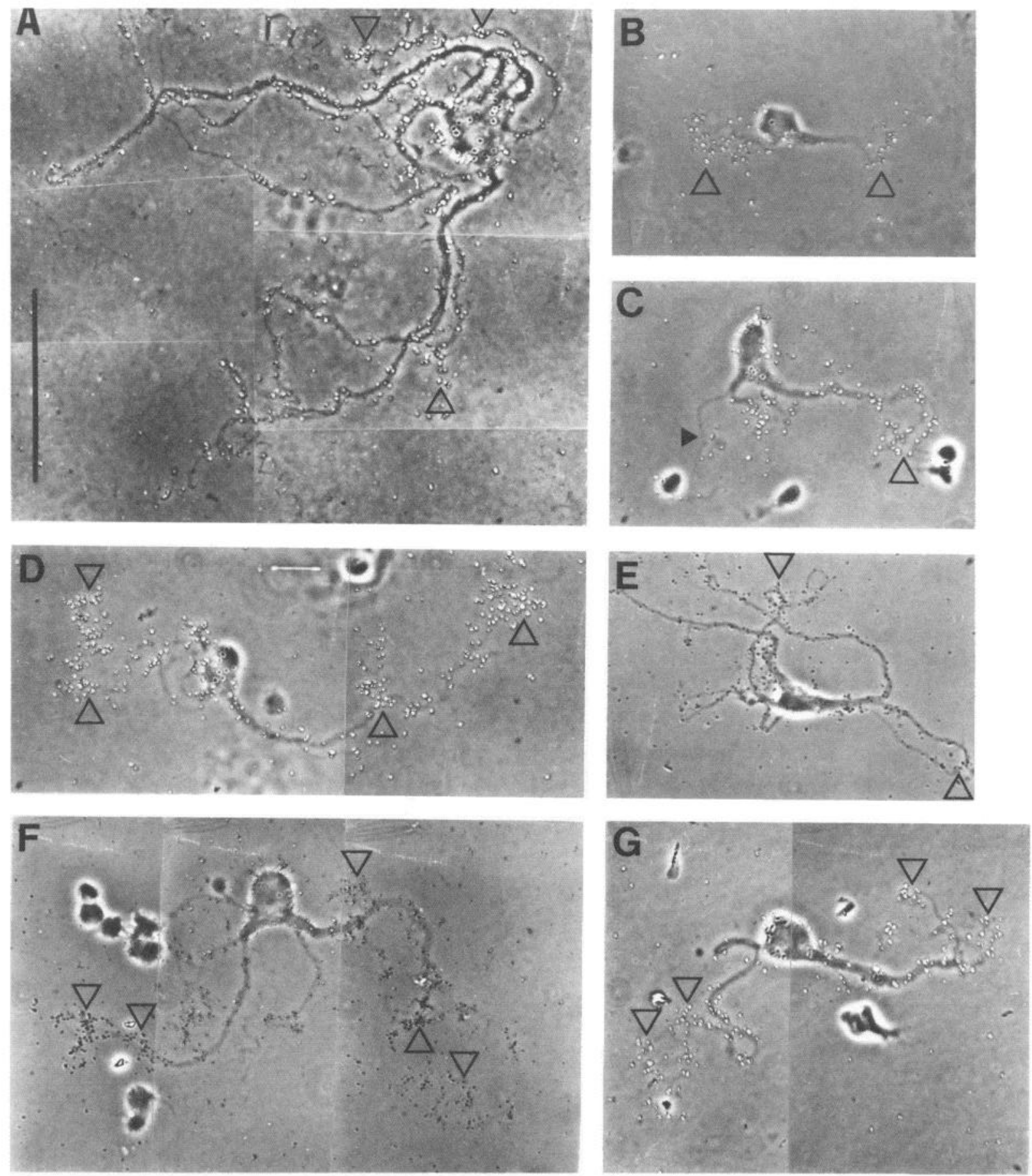

Figure 7. Localization of BTX receptors in peripheral dendrites of various multipolar neurons. Over the wide range of sizes of nicotinic multipolar neurons represented by the cells shown, receptors tended to localize to the periphery of the dendritic arbor (open triangles). A possible axon process, appearing unbranched $(C$, black triangle $)$, as would identify a ganglion cell, had no grains over it. Scale bar $(A), 30 \mu \mathrm{m}$.

Subcellular localization of muscarinic receptors: dendritic segregation early in development

All cells that were muscarinic receptor positive demonstrated a sharp segregation of label between dendrites and cell bodies. Silver grains were abundant over the dendrites but absent elsewhere. Typical examples of this pattern are shown in Figures 3 and 5 . This segregation was observed in small pieces of partially dissociated tissue, as well as in completely isolated neurons. Further specialization occurred within the dendritic arbor itself. When a single dendritic shaft prominently emerged from the cell body, receptors were localized in the peripheral branches rather than the proximal region of the main trunk (e.g., Figs. 3, $A, B, E ; 5, C, D)$.

Isolated cells were obtained from embryos aged E13, E17, and E19 to examine possible reorganization of receptor distri- 

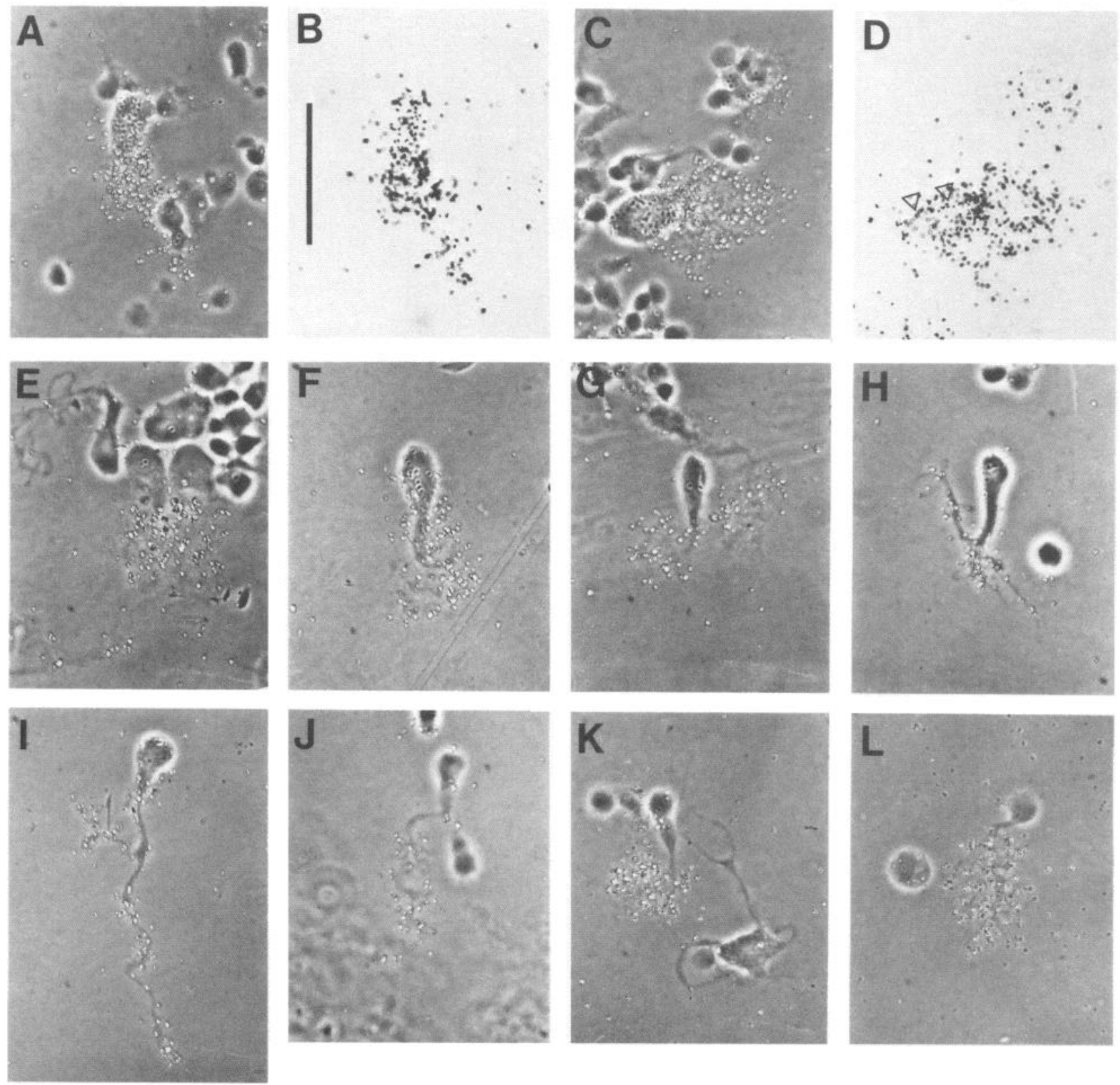

Figure 8. Localization of BTX receptors in cells in other morphological cell subpopulations. Variations in the segmental organization of the dendrites provided different examples of the consistent localization of nicotinic grains to their periphery. A particular type of nicotinic neuron had a tight, "bushy" dendritic form of relatively small extent $(15 \mu \mathrm{m})$ (phase/bright field pairs $A$ and $B$ and $C$ and $D)$ and a medium-sized oval (10 $\times$ $15 \mu \mathrm{m})$ cell body. Most grains were over the dendrites, but dendrites often were relapsed across the body, as suggested by a line of grains $(C$ and $D$, open triangles). Similar cell bodies that were more elongated into a teardrop form had decorated dendrites of comparable size $(E-G)$. Smaller cell bodies shown had a long proximal dendritic shaft that had almost no grains, but the distal or secondary processes were densely decorated $(H-$ L). Scale bar $(B), 30 \mu \mathrm{m}$.

bution during development. These ages were chosen because morphological synapses reportedly first are detectable at E13 and continue to increase during the next week (Daniels and Vogel, 1980). During this period, our data showed no apparent change in muscarinic localization (Fig. 5). Most interestingly, receptors are already localized to dendrites at the time when morphological synapses first appear.

\section{Cellular and subcellular localization of nicotinic receptors}

In overview, cells with nicotinic labeling exhibited major variability in morphologies, in contrast to the relatively homoge- neous subpopulation that expressed muscarinic receptors. At the subcellular level, however, nicotinic receptor distribution resembled the muscarinic pattern in showing restriction to dendrites.

A most striking morphological class of nicotinic-receptorpositive cells comprised those with large cell bodies $(\sim 15 \mu \mathrm{m})$ and outstandingly extensive processes (shown in Figs. 6, 7). The spread of the dendrites on the glass slides often exceeded 100 $\mu \mathrm{m}$. Such large multipolar cells were commonly labeled with ${ }^{125}$ I-BTX. However, as described for the muscarinic labeling, not all cells having morphologies similar to those of receptor- 

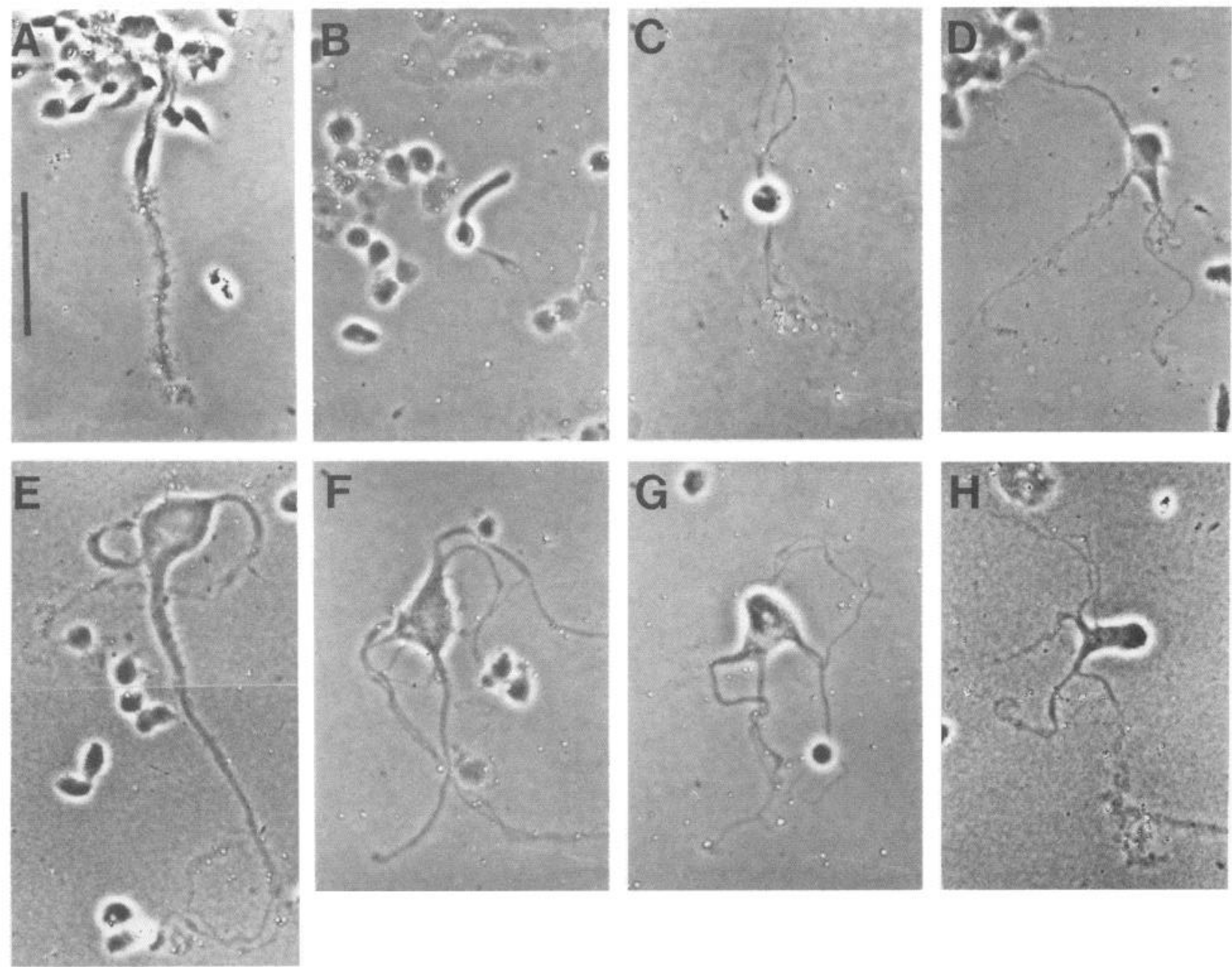

Figure 9. Non-nicotinic cells. Neither Mueller cells $(A)$ nor photoreceptors $(B)$ had nicotinic grains. Other non-nicotinic neurons could be grouped by their general morphological resemblances, and some of these cells might appear similar to some of the nicotinic cells. These included multipolar neurons of different sizes $(C-H)$ and unipolar cells as shown incidentally before Fig. 6,C, $G$, and $E)$. Scale bar $(A), 30 \mu \mathrm{m}$.

positive cells expressed the binding sites. At the subcellular level, only sporadic labeling was seen on cell bodies, and often this was at sites that were crossed by labeled dendrites or loose material. In contrast to the cell bodies, dendrites were profusely labeled.

Because entire cells were visible, it was possible to answer whether all "poles" or "limbs" of a given multipolar neuron contained receptors. A priori the possibility exists that different limbs are biochemically specialized to transduce different neurotransmitters. For the data obtained so far, this was not the case. The examples in Figures 6 and 7 clearly show that the large tapering processes, morphologically presumed to be dendrites (Figs. 6, 7), were all labeled. There was thus no distinguishing one primary limb from another with respect to expression of receptors.

Within the arbor of a primary dendrite, labeling was not uniform. The proximal regions of the primary trunk dendrites often showed little labeling, and maximum grain numbers were generally associated with the distal, smaller-caliber ends. Frequently, the localized grains continued beyond the visible ends of these distal dendrites, indicating dense labeling on the finest branches. Silver grain clusters at the periphery of most arbors suggested differential distribution within a dendritic branch.
Occasionally, a uniform-caliber nonbranching process emerged from a primary dendrite (e.g., Fig. $7 C$ ). Such processes, which may have been axons, were typically unlabeled.

Although the larger cells labeled by BTX seemed to resemble some ganglion and amacrine cell populations seen by Golgi methods in situ, the current study did not seek to establish positive identification of receptor-positive cells. However, consistent morphological differences between these larger cells and those described next implies the occurrence of multiple subpopulations of nicotinic-receptor-positive cells. Additionally, the data show the occurrence of subpopulations that bind BTX but do not bind PrBCM.

As shown in Figure 8, some cells lacked a major dendrite, having instead a fringe of intensely labeled processes that extended immediately out from one hemisphere of a moderatesized cell body. Single processes were usually difficult to view because they had a tendency to aggregate. The actual occurrence and shape of an occasional isolated process could be inferred because the grains deposited over them delineated a "beads-ona-string" figure. These either extended away from the cell body (Fig. 8, $A, B$ ) or they recoursed back over it (Fig. 8, $C, D$ ). Though cell bodies occasionally appeared to bear grains, recurrent processes overlapped the cell body and likely were respon- 

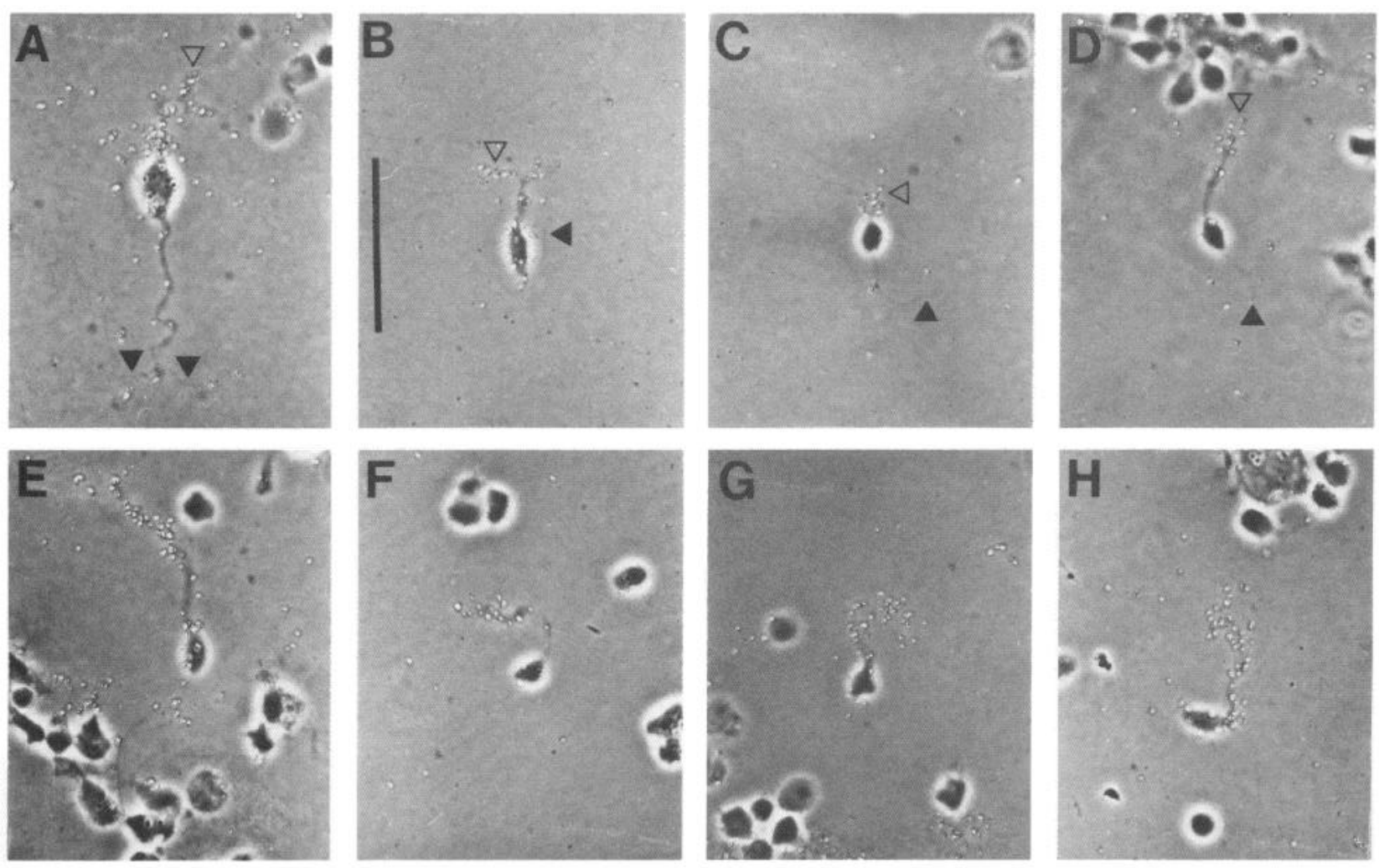

Figure 10. Nicotinic localization in smaller neurons with few processes. Nicotinic receptors occurred on some of the smaller neurons found. These cells could be morphologically identified by 2 thin processes that emerged from opposite poles of the cell body (upper row). Both processes branched in the larger-sized "bipolar" cells $(A)$, but the smallest "bipolar" cells had only one branched process. The grains were localized over distal portions (open triangles) and were fewer over the opposite process (closed triangle). Similar-sized nicotinic cells differed in having only a single branched process (lower row) which was decorated. Calculations of the number of receptors per cell gave the range of $2.5 \times 10^{3}-3 \times 10^{4}$. Scale bar $(B)$, $30 \mu \mathrm{m}$.

sible for at least some of this labeling. As with the cells that had a primary dendrite, it appeared that the narrowest processes provided the sites of the most intensive labeling. From cell to cell, there was considerable variability of labeling within subpopulations. A group of morphologically similar cells in Figure 8 , for example, includes both labeled and unlabeled cells. Further examples of unlabeled cells are shown in Figure 9.

Smaller, elongated cells with single or dual processes also bound BTX. Apparent unipolar cells that were labeled varied from medium sized (Fig. 9) to minuscule (Fig. 10). Of particular interest were the minuscule cells with bipolar morphology. These showed dense labeling on only one process, with minimal or no labeling on the other. This unlabeled process could be an axon of a very small ganglion cell or, perhaps more likely, of a bipolar cell.

\section{Discussion}

In the current study, we have described the positioning of AChRs on neurons isolated from the developing avian retina. The data lead to 3 general conclusions about AChRs within this specific region of the CNS: (1) Muscarinic and putative nicotinic receptors occur, essentially quantitatively, on different classes of neurons; (2) receptor molecules are preferentially directed to dendrites; and (3) sequestering of receptors to dendrites occurs prior to the major developmental increase in synaptic junction profiles.

The approach we have used to isolate arborized neurons from the avian system was pioneered by Lam and his colleagues in studies of the turtle retina (reviewed by Sarthy, 1986). Disruption of cell-cell interactions by gentle mechanical agitation, facilitated by use of the proteolytic enzyme papain, gave surprisingly well-preserved neurons. The best of the isolated neurons resembled to some extent various Golgi-stained preparations (Castro, 1966; Cajal, 1972; Galvez et al., 1977). Two advantages of the approach were apparent. First, the hundreds of cells that were examined could be organized into simple groups based on sizes of cell bodies and patterns of arborization. This allowed comparison of receptor expression among various morphological subpopulations. Second, each individual cell could be examined in overview to answer questions about subcellular positioning. The major disadvantage of the approach was the use of papain, which a priori can be expected to attack membrane proteins nonspecifically, including neurotransmitter receptors. In the current work, however, we found papain did not lower the level of AChRs. Previous studies have shown that neuroreceptor function, as well as various other aspects of cellular physiology, are well preserved (Sarthy, 1986). Ultrastructural studies have shown that papain-dissociated neurons have no presynaptic terminals adhering to them (Vogt et al., 1987; Lankford and Klein, unpublished data).

In distinguishing cells that express $\mathrm{AChR}$, we have used ${ }^{125} \mathrm{I}-$ BTX and ${ }^{3} \mathrm{H}-\mathrm{PrBCM}$ as specific receptor markers. PrBCM is in routine use as a muscarinic ligand (Burgen et al., 1974; Rotter, et al., 1979a, b), but there has been considerable controversy regarding the nature of the BTX receptor. For the avian CNS, however, available data indicate that, while BTX may not be a 
physiologically competent antagonist, it is nonetheless a useful pharmacological marker for nicotinic receptors (Vogel and $\mathrm{Ni}$ renberg, 1976; Wang et al., 1978; Betz et al., 1982; Siman and Klein, 1983). Neuronal nicotinic receptor molecules displaying BTX binding in brain and peripheal tissues appear to comprise tissue-specific groups, with further heterogeneity distinguished by the binding of BTX or other equally specific probes. The neuronal BTX receptor isolated from chick brain has the properties of a nicotinic cholinergic receptor, e.g., it has high-affinity binding for nicotinic ligands (Schneider et al., 1985) and it can be immunoprecipitated by antibodies raised against nicotinic receptors from muscle (Barnard et al,, 1983). Chicken BTX receptors purified from brain, optic lobe, or muscle are structurally similar (Norman et al., 1982), and their subunits display scquence homologics (Conti-Tronconi et al., 1985). Different nicotinic receptor proteins exist in chicken brain that do not bind BTX (Whiting et al., 1987), but an emerging consensus is that such receptors, along with BTX receptors, are products of an extended family of homologous genes (Whiting and Lindstrom, 1987). Ultrastructural studies have shown specific BTX binding at chick retina synapses (Vogel et al., 1977; Daniels and Vogel, 1980). The data obtained here, showing a high degree of specific localization of BTX receptors at the histological, cellular, and subcellular levels, are consistent with a synaptic receptor function.

For future work, the possibility of examining isolated neurons with multiple markers specific for cell types, neurotransmitters and neuropeptides, ion channels, and mRNA seems especially promising. In our current effort, the use of simple morphological criteria was sufficient to answer the question of whether muscarinic and nicotinic receptors were expressed on different cell types. Cholinergic receptor types occurred on cells that were easily distinguishable, with muscarinic receptors particularly restricted in their cellular distribution. Muscarinic receptors only were observed on cells with very small cell bodies having a single emergent arbor. This arbor sometimes was more elongated and sometimes more bushy and plexuslike, indicating subtle morphological variations within the subpopulation. Nicotinic receptors occurred on a variety of cell types, including unipolar, hipolar, and multipolar cells of various sizes. They were particularly common on very large multipolar cells.

The autoradiographic data, directly showing differential labeling of cells by muscarinic and nicotinic ligands, are consistent with inferences drawn from toxicological experiments. On the basis of changes in binding levels associated with differential sensitivity of chick retina cells to kainic acid or colchicine (Morgan and Mundy, 1982; Redburn et al., 1984), it was inferred that only nicotinic receptors occurred on ganglion cells, that both types occurred on amacrine cells, and that perhaps both types occurred on bipolar cells. Ultrastructural studies of chick retina have suggested the possibility that nicotinic receptors occur on ganglion and amacrine cells and on axons of bipolar cells. The current autoradiographs show frequent and abundant labeling by BTX of large multipolar cells, some of which had apparent axons and may have been ganglion cells. Such cells were never labeled by PrBCM. These data provide support for the hypothesis that only nicotinic receptors occur on ganglion cells. Bipolar cells also were labeled with BTX but not PrBCM. Neither cholinergic ligand was ever seen in association with photoreceptor or Mueller cells. With the recent development of cDNA probes for muscarinic and nicotinic receptors in the CNS (Numa et al., 1983; Bonner et al., 1987), the factors that deter- mine cell-specific differentiation in relation to receptor gene expression should become amenable to analysis (Goldman et al., 1986).

The separation of muscarinic and nicotinic receptors to different classes of cells is consistent with their apparently different roles in information processing. It has been suggested (reviewed by Purves, 1976; Hartzell, 1981; Brown, 1983) that the rapidly responding nicotinic receptor might generally mediate transmission of frequency-coded information, while the slowly responding muscarinic receptor might generally mediate more prolonged changes in neuronal excitability. Although little is known about the specific function of cholinergic synapses in chick retina, studies suggest stimulatory functions directed to amacrine cells (reviewed by Puro, 1985; Masland and Tauchi, 1986). The amacrine cell population, thought to be the principal source of $\mathrm{ACh}$ in all vertebrates examined, including chicken (Baughman and Bader, 1977; Eckenstein et al., 1981; Millar et al., 1985), contributes excitatory input to a variety of characterized patterns of ganglion cell discharges.

If the BTX binding sites in the outer synaptic layer were functional AChRs, a cholinergic input besides the amacrine population would be predicted, as amacrine cells branch and synapse in the inner synaptic layer. In chicken retina, there is a small population of apparent cholinergic neurons in the middle of the inner nuclear layer (Baughman and Bader, 1977) that conceivably could provide innervation to cholinoceptive sites in the outer synaptic layer. The receptor sites seem most likely to be associated with bipolar cells, which were BTX-labeled, or with horizontal cells. BTX-labeled "bushy" cells with very many short unbranched dendrites (Fig. 8) have a morphology consistent with horizontal cells. In the turtle retina, bipolar cell dendrites are the predominant locus of BTX labeling (James and Klein, 1984). Yazulla and Schmidt (1977) also have reported BTX binding outer synaptic layer of the pigeon, but they observed that only BTX binding in the inner synaptic layer is displaceable by nicotine. However, the data in Figure 1 show that $0.1 \mathrm{~mm} d$-tubocurarine effectively blocks binding in both layers. Conceivably, differences may reflect binding to subclasses of nicotinic receptors, perhaps reflecting different developmental, metabolic, or functional states.

By examining receptor placement over the entire surfaces of isolated CNS cells, we obtained data germane to the hypothesis that neurons, like muscle cells, show synaptically specialized receptor localization. Consistent with this hypothesis, the total number of receptors, for both muscarinic and nicotinic systems, was very much greater on dendrites than on cell bodies. When placement of silver grains gave the impression that receptors occurred on cell bodies, closer inspection typically revealed that grains were due to folded dendrites. Examination of the dendritic populations showed that receptors tended to localize to thin processes. These were secondary branches in large, arborescent cells (but apparently primary dendrites in small, bushy cells), and this localization may account for the stratification of receptor positioning seen in the inner plexiform layer of sectioned retina tissue (Sugiyama et al., 1977). Many of these processes were so thin that only the positioning of the grains revealed their shape. In the outermost branches of large neurons, there were linear clusters of grains separated by regions of scarcity. Overall, the larger primary dendritic "limbs" typically showed less labeling than the finer dendritic branches.

For the dendritic arbors of all multipolar cells, receptors occurred in each sector defined by a primary dendritic limb. We 
never observed a case wherein, for example, 3 limbs were abundantly labeled but 1 was not. However, the axonlike processes occasionally retained by some large multipolar cells were never labeled. Furthermore, only one process in bipolar cells was receptor positive. If the labeled bipolar process, with its tuft of ramifications, were a dendrite, it could account for the labeling found in the outer synaptic layer. Overall, the data demonstrate a ccll surface differentiation of receptor distribution that is associated with functional segmentation.

Developmentally, it was found that the cell surface differentiation of receptors occurred very early. At E13, prior to the rapid rise in synaptic profiles seen with the electron microscope, receptors were already restricted to dendrites. Conceivably, fine tuning of receptor positioning may be taking place subsequent to this early restriction. Recent biochemical studies have shown that muscarinic receptors are functionally competent prior to the appearance of synaptic junctions but that significant developmental changes continue to occur. These changes include an increase in agonist binding affinity, a decreased isoelectric point, and a $14 \mathrm{kDa}$ decrease in apparent molecular weight (Large et al., 1985a, b). Biochemical modifications could be associated with positional information.

The pattern of receptor distributions seen here, in which receptors occurred preferentially in distal processes, while trunk segments and cell bodies were receptor free, suggests the activity of directional transport or receptor-specific anchoring mechanisms. Ultrastructural networks seem likely to play a role in receptor guidance and membrane differentiation. Since it is possible to readily observe such networks in isolated retina neurons as whole mounts using the high-voltage electron microscope (Tsui et al., 1983), futurc studics of mechanisms underlying receptor positioning and turnover in differentiated CNS cells seem feasible. In addition, as it has been shown that avian retinal neurons grown in monolayer can express abundant muscarinic receptors on their cell bodies (Large et al., 1985a), studies of the role of cell-cell interactions in controlling the positioning process should also prove valuable.

\section{References}

Adler, R., and Faber, D. (1986) The Retina: A Model for Cell Biology Studies, Academic, New York.

Barnard, E. A., D. Beeson, G. Bilbe, D. A. Brown, A. Constanti, B. M. Conti-Tronconi, J. O. Dolly, S. M. J. Dunn, R. Mehraban, B. M. Richards, and T. G. Smart (1983) Acetylcholine and GABA receptors: Subunits of central and peripheral receptors and their encoding nucleic acids. Cold Spring Harbor Symp. Quant. Biol. 48: 109-124.

Baughman, R. W., and C. R. Bader (1977) Biochemical characterization and cellular localization of the cholinergic system in the chicken retina. Brain Res. 138: 469-485.

Betz, H. (1983) Regulation of alpha-bungarotoxin accumulation in chick retina cultures: Effects of membrane depolarization, cyclic nucleotide derivatives and $\mathrm{CaCl}_{2}$. I. Neurosci. 3: 1333-1341.

Betz, H., D. Graham, and H. Rehm (1982) Identification of polypeptides associated with a putative neuronal nicotinic acetylcholine receptor. J. Biol. Chem. 257: 11390-11394.

Bonner, T. I., N. J. Buckley, A. C. Young, and M. R. Brann (1987) Identification of a family of muscarinic acetylcholine receptor genes. Science 237:527-532.

Brown, D. A. (1983) Slow cholinergic excitation-A mechanism for increasing neuronal excitability. Topics Neurosci. 6: 302-307.

Burgen, A. S. V., C. R. Hiley, and J. M. Young (1974) The binding of [ $\left.{ }^{3} \mathrm{H}\right]$ propylbenzilcholine mustard by longitudinal muscle strips from guinea-pig small intestine. Br. J. Pharmacol. 50: 145-151.

Castro, G. O. (1966) Branching pattern of amacrine cell processes. Nature 212: 832-834.
Conti-Tronconi, B. M., S. M. J. Dunn, E. A. Barnard, J. O. Dolly, F. A. Lai, N. Ray, and M. A. Raftery (1985) Brain and muscle nicotinic acetylcholine receptors are different but homologous proteins. Proc. Natl. Acad. Sci. USA 82: 5208-5212.

Daniels, M. P., and Z. Vogel (1980) Localization of alpha-bungarotoxin binding sites in synapses of the developing chick retina. Brain Res. 201: 45-56.

Dowling, J. E. (1975) Local circuit neurons in the vertebrate retina. In Local Circuit Neurons, P. Rakic, ed., MIT Press, Cambridge, MA.

Eckenstein, R., M. Schwab, and H. Thoenen (1981) Cholineacetyltransferase: Purification and immunofluorescent localization in the retina of four vertebrate species. Soc. Neurosci. Abstr. 7: 309.

Fertuck, H. C., and M. M. Salpeter (1976) Quantitation of junctional and extrajunctional acetylcholine receptors by electron microscope autoradiography after ${ }^{125}$ I-alpha-bungarotoxin binding at mouse neuromuscular junctions. J. Cell Biol. 69: 144-158.

Galvez, J. M. G., L. Puelles, and C. Prada (1977) Inverted (displaced) retinal amacrine cells and their embryonic development in the chick. Exp. Neurol. 56: 151-157.

Goldman, D., D. Simmons, L. W. Swanson, J. Patrick, and S. Heinemann (1986) Mapping of brain areas expressing RNA homologous to two different acetylcholine receptor alpha-subunit cDNAs. Proc. Natl. Acad. Sci. USA 83: 4076-4080.

Grun, G. (1982) Development dynamics of synapses in the vertebrate retina. Prog. Neurobiol. 18: 257-274.

Hartzell, H. C. (1980) Distribution of muscarinic acetylcholine receptors and presynaptic nerve terminals in amphibian heart. J. Cell Biol. 86: 6-20.

Hartzell, H. C. (1981) Mechanism of slow synaptic potentials. Nature 292: 539-544.

James, W. M., and W. L. Klein (1982) Autoradiography of dendritic acetylcholine receptors: A method for study of isolated neurons from the adult central nervous system of the turtle. Neurosci. Lett. 32: 510.

James, W. M., and W. L. Klein (1984) Alpha-bungarotoxin receptors on neurons isolated from turtle retina: Molecular heterogeneity of bipolar cells. J. Neurosci. 5: 352-361.

Klein, W. L. (1984) Biochemistry and regulation of signal transduction by neuronal acetylcholine receptors. Curr. Topics Cell. Regulat. 24: $129-144$.

Kuhar, M. J. (1987) Recent progress in receptor mapping: Which neurons contain the receptors? TINS 10: 308-310.

Kuhar, M. J., E. B. De Souza, and J. Unnerstall (1986) Neurotransmitter receptor mapping by autoradiography and other methods. Annu. Rev. Neurosci. 9: 27-60.

Lane, M.-A., A. Sastre, M. Law, and M. M. Salpeter (1977) Cholinergic and adrenergic receptors on mouse cardiocytes in vitro. Dev. Biol. 57: 254-269.

Large, T. L., N.-J. Cho, F. G. DeMello, and W. L. Klein (1985a) Molecular alteration of a muscarinic acetylcholine receptor system during synaptogenesis. J. Biol. Chem. 260: 8873-8881.

Large, T. L., J. J. Rauh, F. G. DeMello, and W. L. Klein (1985a) Two molecular-weight forms of muscarinic acetylcholine receptors in the a vian central nervous system: Switch in predominant molecular weight form during differentiation of synapses. Proc. Natl. Acad. Sci. USA 82: 8785-8789.

Masland, R. H., and M. Tauchi (1986) The cholinergic amacrine cell. Topics Neurosci. 9: 218-223.

Millar, T., I. Ishimoto, C. D. Johnson, M. L. Epstein, I. W. Chubb, and I. G. Morgan (1985) Cholinergic and acetylcholinesterase-containing neurons of the chicken retina. Neurosci. Lett. $61: 311-316$.

Morgan, I. G., and P. G. Mundy (1982) Ganglion cells of chicken retina possess nicotinic rather than muscarinic acetylcholine receptors. Neurochem. Res. 7: 267-274.

Morley, B. J., and G. E. Kemp (1981) Characterization of a putative nicotinic acetylcholine receptor in mammalian brain. Brain Res. Rev. 3: 81-104.

Norman, R. I., F. Mehraban, E. A. Barnard, and J. O. Dolly (1982) Nicotinic acetylcholine receptor from chick optic lobe. Proc. Natl. Acad. Sci. USA 79: 1321-1325.

Numa, S., M. Noda, H. Takahashi, T. Tanabe, M. Toyosato, Y. Furutani, and S. Kikyotani (1983) Molecular structure of the nicotinic acetylcholine receptor. Cold Spring Harbor Symp. Quant. Biol: 48: 57-70.

Puro, D. G. (1985) Cholinergic systems. In Retinal Transmitters and 
Modulators: Models for the Brain, pp. 64-91, CRC Press, Boca Raton, FL.

Purves, R. D. (1976) Function of muscarinic and nicotinic acetylcholine receptors. Nature 261: 149-151.

Ramón y Cajal, S. (1972) The Structure of the Retina, S. A. Thorpe and M. Glickstein, eds., pp. 76-121, Thomas, Springfield, IL

Redburn, D. A., J. A. Donoso, C. K. Mitchell, P. Gomez-Ranis, and F. E. Samson (1984) Kainic acid-induced denervation supersensitivity of the nicotinic, cholinergic receptors in ganglion cells of the rat retina. Exp. Eye Res. 38: 449-461.

Rotter, A., N. J. M. Birdsall, A. S. V. Burgen, P. M. Field, E. C. Hulme and G. Raisman (1979a) Muscarinic receptors in the central nervous system of the rat. I. Technique for autoradiographic localization of the binding of $\left[{ }^{3} \mathrm{H}\right]$ propylbenzilcholine mustard and its distribution in the forebrain. Brain Res. Rev. 1: 141-165.

Rotter, A. N., N. J. M. Birdsall, P. M. Field, and G. Raisman (1979b) Muscarinic receptor in the central nervous system of the rat. II. Distribution of binding of $\left[{ }^{3} \mathrm{H}\right]$ propylbenzilcholine mustard in the midbrain and hindbrain. Brain Res. Rev. 1: 167-183.

Sarthy, P. V. (1986) Retinal neurons: Their separation and characterization. Prog. Retinal Res. 6: 45-67.

Schneider, M., C. Adee, H. Betz, and J. Schmidt (1985) Biochemical characterization of two nicotinic receptors from the optic lobe of the chick. J. Biol. Chem. 260: 14505-14512.

Schuetze, S. M., and L. W. Role (1987) Developmental regulation of nicotinic acetylcholine receptors. Annu. Rev. Neurosci. 10: 403-458.

Siegel,. R. E., and G. D. Fischbach (1984) Muscarinic receptors and responses in intact embryonic chick atrial and ventricular heart cells. Dev. Biol. 101: 346-356.

Siman, R. G., and W. L. Klein (1983) Differential regulation of muscarinic and nicotinic receptors by cholinergic stimulation in cultured avian retina cells. Brain Res. 262: 99-108.

Sugiyama, H., M. P. Daniels, and M. Nirenberg (1977) Muscarinic acetylcholine receptors of developing retina. Proc. Natl. Acad. Sci. USA 74: 5524-5528.

Tsui, H.-C. T., H. Ris, and W. L. Klein (1983) Ultrastructural networks in growth cones and neurites of cultured central nervous system neurons. Proc. Nat1. Acad. Sci. USA 80: 5779-5783.

Vogel, Z., and M. Nirenberg (1976) Localization of acetylcholine receptors during synaptogenesis in retina. Proc. Natl. Acad. Sci. USA 73: $1806-1810$.

Vogel, Z., G. J. Maloney, A. Ling, and M. P. Daniels (1977) Identification of synaptic acetylcholine receptor sites in retina with peroxidase-labeled alpha-bungarotoxin. Proc. Natl. Acad. Sci. USA 74: 3268-3272.

Vogt, B. A., E. Townes-Anderson, and D. L. Burns (1987) Dissociated cingulate cortical neurons: Morphology and muscarinic receptor binding properties. J. Neurosci. 7: 959-971.

Wang, G.-K., S. Molinaro, and J. Schmidt (1978) Ligand responses of alpha-bungarotoxin binding sites from skeletal muscle and optic lobe of the chick. J. Biol. Chem. 253: 8507-8512.

Whiting, $P_{\text {., }}$ and $J$. Lindstrom (1987) Purification and characterization of a nicotinic acetylcholine receptor from rat brain. Proc. Natl. Acad. Sci. USA 84: 595-599.

Whiting, P. J., R. Liu, B. J. Morley, and J. M. Lindstrom (1987) Structurally different neuronal nicotinic acetylcholine receptor subtypes purified and characterized using monoclonal antibodies. J. Neurosci. $7: 4005-4016$

Yazulla, S., and J. Schmidt (1977) Two types of receptors for alphabungarotoxin in the synaptic layers of the pigeon retina. Brain Res. 138: 45-57.

Zarbin, M. A., J. K. Wamsley, J. M. Palacios, and M. J. Kuhar (1986) Autoradiographic localization of high affinity GABA, benzodiazepine, dopaminergic, adrenergic and muscarinic cholinergic receptors in the rat, monkey and human retina. Brain Res. 347: 75-92. 